\title{
Pengaruh Citra Merek Terhadap Keputusan Pembelian Pada PT Astra International, Tbk Toyota Auto 2000 Bumi Serpong Damai
}

\author{
Cornelia Dumarya Manik ${ }^{1}$ \\ ${ }^{1}$ Jurusan Manajemen, Fakultas Ekonomi, Universitas Pamulang, \\ Jl. Surya Kencana No.1 Pamulang Barat, Kota Tangerang Selatan, 15417 \\ Penulis untuk Korespondensi/Email: corneliaduma25@gmail.com
}

\begin{abstract}
Abstrak - Penelitian ini bertujuan untuk mengetahui seberapa besar pengaruh citra merek terhadap keputusan pembelian pada PT. Astra International, Tbk-Toyota Auto 2000 cabang Bumi Serpong Damai. Penelitian ini dilaksanakan di PT. Astra International, Tbk-Toyota Auto 2000 cabang Bumi Srpong Damai. Model penelitian yang digunakan yakni dengan metode observasi, wawancara, kuesioner dan studi kepustakaan yang dilakukan secara sistematik berdasarkan tujuan penelitian. Metode penelitian ini menggunakan metode kuantitatif, asosiatif dengan populasi dalam penelitian ini adalah pelanggan yang melakukan service berkala pada PT. Astra International, Tbk-Toyota Auto 2000 cabang Bumi Serpong Damai, dalam waktu 5 ( lima ) tahun yaitu sebanyak 624 pelanggan. Metode penarikan sampel menggunakan rumus Slovin didapat sebanyak 86 responden. Metode analisis dalam pengolahan data adalah uji validitas dan reliabilitas, uji regresi linear sederhana, koefisien determinasi, uji hipotesis (uji-t), dan uji korelasi pearson product moment untuk mengetahui seberapa besar pengaruh citra merek terhadap keputusan pembelian mobil Toyota Yaris. Berdasarkan hasil penelitian dan pembahasan diperoleh hasil, bahwa terdapat pengaruh hubungan positif antara citra merek terhadap keputusan pembelian sebesar 0,602 sehingga adanya hubungan antara citra merek terhadap keputusan pembelian, dari hasil regresi lienar sederhana dapat dilihat persamaan yang bernilai $y=16.546+0,583 X$. Yang memiliki arti bahwa variabel citra merek berpengaruh positif terhadap keputusan pembelian konsumen, dari hasil uji determinasi sebesar 0,362. Hal ini menunjukkan bahwa sebesar 36,2\% Keputusan Pembelian konsumen terhadap pembelian mobil Toyota Yaris dipengaruhi oleh variasi dari ketiga variabel independen, yaitu keunggulan asosiasi merek, kekuatan asosiasi merek, keunikan asosiasi merek, Sedangkam sisanya sebesar $63,8 \%$ dipengaruhi oleh variabel-variabel lainnya yang tidak diteliti. Hasil $t$ hitung adalah 6,907 lebih besar dari $t$ tabel yaitu 1,9886. Oleh karena itu t-hitung lebih kecil daripada t-tabel, maka H0 ditolak dan Ha $\neq 0$ diterima. Ini menunjukkan bahwa antara pengaruh citra merek terhadap keputusan pembelian terdapat pengaruh yang signifikan.
\end{abstract}

\section{Kata Kunci : Citra merek, Keputusan Pembelian.}

Abstract - This research was conducted on PT. Astra International, Tbk-Toyota Auto 2000 branch of Bumi Serpong Damai. The research model used is the method of observation, interviews, questionnaires and literature studies conducted systematically based on research objectives. This research method using quantitative method, associative with population in this research is customer who do periodical service on PT. Astra International Tbk-Toyota Auto 2000 branch Bumi Serpong Damai, within 5 (five) years as many as 624 customers. Sampling method using Slovin formula obtained as many as $\mathbf{8 6}$ respondents. Method of analysis in data processing is test of validity and reliability, simple linear regression test, coefficient of determination, hypothesis test ( $t$ - test), and Pearson product moment correlation test to find out how much the influence of the brand image of Toyota Yaris car purchase decision. Based on the results of research and discussion obtained the results, that there is influence positive relationship between the brand image to purchase decision of 0.602 so that the relationship between the brand image of the 
purchase decision, from the results of simple lienar regression can be seen the equation $y=16,546$ $+0,583 X$. Which means that brand image variables have a positive effect on consumer purchasing decisions, from the test determination of $\mathbf{0 . 3 6 2}$. This shows that $\mathbf{3 6 , 2 \%}$ Consumer purchasing decision on Toyota Yaris car purchase is influenced by variation from three independent variables, namely the superiority of brand association, the strength of brand association, uniqueness of brand association, the remaining cages of $63,8 \%$ influenced by the variables others not examined. Result $t$ count is 6,907 bigger than $t$ table that is 1,9886. Therefore $t$-count is smaller than $\mathrm{t}$-table, then $\mathrm{HO}$ is rejected and $\mathrm{Ha} \neq 0$ is accepted. This shows that between the influence of brand image to purchase decision there is a significant influence.

Keywords : Brand image, Purchase Decision.

\section{PENDAHULUAN}

\section{Latar Belakang Masalah}

PT. Astra International Tbk- Toyota Sales Operation (TSO) atau lebih dikenal dengan nama AUTO 2000 selaku main dealer Toyota yang menyediakan penjualan (Sales), perbaikan (Service), dan suku cadang (Sparepart) untuk seluruh pelanggan Toyota baik itu perorangan, perusahaan dan instansi pemerintah, melihat posisi Auto 2000 sebagai market leader Toyota, manajemen terus berusaha untuk meraih best brand.

Salah satu survei merek di Indonesia yang dijadikan sebagai indikator kinerja sebuah merek adalah Top Brand Award. Survei ini dipelopori oleh majalah "MARKETING" yang bekerja sama dengan lembaga survei Frontier Consulting Group. Konsep tentang Top Brand mengenai merek suatu produk didasarkan pada tiga parameter yaitu: merek yang paling diingat (top of mind), merek yang terakhir kali dibeli atau dikonsumsi (last used), serta merek yang akan dipilih kembali di masa mendatang (future intention). Ketiga parameter tersebut diformulasikan dengan cara menghitung ratarata terboboti masing-masing parameter untuk membentuk Top Brand Index (TBI). Kriteria yang harus dipenuhi agar sebuah merek berhak menyandang predikat Top Brand adalah memperoleh Top Brand Index minimum sebesar $10 \%$ dan berada dalam posisi top three di dalam kategori produknya. Dengan adanya dua kriteria tersebut tidak menutup kemungkinan dalam satu kategori produk terdapat lebih dari satu merek - maksimal tiga merek yang meraih predikat Top Brand. Honda Jazz, Toyota Yaris, Suzuki Swift, KIA Picanto, Suzuki Karimun, dan Daihatsu Alya sebagai mobil segmen City Car yang mendominasi penjualan mobil segmen City Car di Indonesia. Honda Jazz dimana dalam tiga tahun terakhir ini selalu berhasil meraih predikat Top Brand tertinggi di bandingkan dengan Suzuki Swift, KIA Picanto, Suzuki Karimun, dan Daihatsu Alya.

Tabel 1. Data Penjualan Mobil Yaris 2013-2017

\begin{tabular}{llllll}
\hline MEREK & \multicolumn{5}{c}{ TAHUN / UNIT } \\
\cline { 2 - 6 } MOBIL & 2013 & 2014 & 2015 & 2016 & 2017 \\
$\begin{array}{c}\text { Toyata } \\
\text { Yaris }\end{array}$ & 51 & 182 & 185 & 125 & 81 \\
\hline
\end{tabular}

Sumber: Toyota Dealer Management System-

AUTO 2000 BSD

Namun tidak demikian dengan Toyota Yaris pada tahun 2016 menurun, hal ini menunjukan bahwa minat konsumen untuk membeli Toyota Yaris cenderung turun, penyebabnya adalah bensin boros, kadang kurang tenaga saat melewati tanjakan, suspense keras, tarikan kurang responsif dan trend pemakain mobil City Car bergeser ke mobil yang harganya lebih murah. Auto 2000 memanfaatkan event ini untuk melakukan berbagai perbaikan di intern perusahaan, meningkatkan kepuasan pelanggan dan event ini merupakan suatu cara untuk mengukuhkan Top Brand Toyota dan menguatkan merek Toyota menjadi lebih dikenal oleh masyarakat luas, bahkan untuk menarik segmen-segmen yang lain. Berdasarkan permasalahan diatas, peneliti memilih melakukan penelitian pada PT.Astra International Tbk- Toyota Auto 2000 Bumi Serpong Damai yang terletak di BSD Komersial VII C No.2 \& 2A Serpong Tangerang, menyadari pentingnya layanan purna jual untuk memberikan kepuasan pelanggan, meningkatkan loyalitas pelanggan Toyota dan meningkatkan citra merek Toyota serta meningkatkan minat pembelian maka hal 
tersebut menjadi daya tarik sendiri bagi peneliti untuk meneliti tanggapan konsumen terhadap citra merek dan kualitas pelayanan bagian service dalam mendukung penjualan kendaraan mobil merk Toyota, untuk itu penulis mencoba menelitinya dalam bentuk skripsi yang berjudul

"Pangaruh Citra Merek Terhadap Keputusan Pembelian Mobil Toyota Yaris Pada PT. Astra International, Tbk-Toyota AUTO 2000 Bumi Serpong Damai’”.

\section{Tujuan Penelitian}

Berdasarkan perumusan masalah, maka tujuan penelitian ini adalah:

a. Untuk mengetahui citra merek Toyota Yaris yang dipersepsikan konsumen.

b. Untuk mengetahui pengambilan keputusan pembelian Toyota Yaris pada Auto 2000 Bumi Serpong Damai.

c. Untuk mengetahui pengaruh citra merek terhadap pengambilan keputusan pembelian pada Auto 2000 Bumi Serpong Damai.

\section{Manfaat Penelitian}

Berdasarkan tujuan penelitian diatas, maka penelitian ini diharapkan bermanfaat:

a. Bagi Penulis

Dapat menerapkan ilmu-ilmu yang telah didapatkan selama masa kuliah dalam menunjang aktifitas pekerjaan sehari-hari khususnya ilmu ekonomi dan manajemen pemasaran.

b. Bagi Perusahaan

Dengan adanya penelitian ini diharapkan perusahaan mengetahui seberapa besar pengaruh faktor brand image dan kualitas pelayanan yang telah diberikan kepada seluruh pelanggan Toyota selama inidan untuk memperbaiki segala sesuatu yang dianggap masih perlu untuk dilakukan perbaikan.

c. Bagi Akademis

Memberikan informasi yang bermanfaat dan sebagai sumber referensi bagi peneliti lain yang juga sedang melakukan penelitian atau mengembangkan penelitian yang relevan.

\section{TINJAUAN PUSTAKA}

\section{Manajemen Pemasaran}

Pengertian Manajemen

Manajemen berasal dari kata to manage yang berarti mengelola, menata, mengurus, melakukan dan mengendalikan. Untuk mengetahui dan memahami lebih jauh pengertian manajemen maka diberikan definisi manajemen berdasarkan para ahli (Ardana, 2012; 4):

Manajemen menurut James Stoner, proses perencanaan, pengorganisasian, pemimpinan dan pengendalian upaya anggota organisasi dan proses penggunaan semua sumber daya dalam organisasi untuk mencapai tujuan organisasi yang telah ditetapkan. Manajemen menurut Harold Koonntz dan C.O. Dannel, upaya mencapai tujuan organisasi melalui kegiatan orang lain. Manajemen menurut Heene dan Desmidt (2010:8), serangkaian aktivitas manusia yang berkesinambungan dalam mencapai suatu tujuan yang telah ditetapkannya. Manajemen menurut M.P. Fallet yang dikutip oleh T. Hani handoko, sebagai seni dalam menyelesaikan pekerjaan melalui orang lain. Berdasarkan pengertian diatas maka pengertian manajemen adalah ilmu dan seni mengatur proses pemanfaatan sumber daya manusia dan sumber lainnya secara efektif dan efisien untuk mencapai tujuan tertentu (Ardana, 2012:4).

\section{Pengertian Merek}

Sebuah merek yang terkenal dan terpercaya merupakan aset yang tidak ternilai. Keahlian yang paling unik dari pemasaran yang professional adalah kemampuannya untuk menciptakan, memelihara, melindungi, dan meningkatkan merek. Menurut Kotler dalam Fandy Tjiptono (2015: 105) menyusun paham bahwa ada enam makna yang bisa di sampaikan melalui suatu merek, yaitu pada halaman selanjutnya:

1. Sarana identifikasi untuk memudahkan proses penanganan atau pelacakan produk bagi perusahaan.

2. Bentuk proteksi hukum terhadap fitur atau aspek produk yang unik.

3. Signal tingkat kualitas bagi para pelanggan yang puas, signal tingkat kualitas bagi para pelanggan yang puas, sehingga mereka bisa dengan mudah memilih dan membelinya lagi di lain waktu.

4. Sarana menciptakan asosiasi dan makna unik yang membedakan produk dari para pesaing.

5. Sumber keunggulan kompetitif, terutama 
melalui perlindungan hukum, loyalitas pelanggan, dan citra unik yang berbentuk dalam benak konsumen.

6. Sumber finansial returns terutama menyangkut pendapatan masa depan.

Menurut Undang - undang Merek no 15 tahun 2001 pasal 1 ayat 1 dalam Fandy Tjiptono (2015: 3) yaitu "Merek adalah tanda yang berupa gambar, nama, kata, huruf huruf, angka angka, susunan warna, atau kombinasi dari unsur-unsur tersebut yang memiliki daya pembeda dan digunakan dalam kegiatan perdagangan barang atau jasa".

\section{Pengertian Citra Merek}

Citra merek merupakan serangkaian asosiasi (persepsi) yang ada dalam benak konsumen terhadap suatu merek, biasanya terorganisasi menjadi suatu makna. Hubungan terhadap suatu merek akan semakin kuat jika didasarkan pada pengalaman dan mendapat banyak informasi. Citra atau asosiasi merepresentasikan persepsi yang bisa merefleksikan kenyataan yang objektif ataupun tidak. Citra yang terbentuk dari asosiasi (presepsi) inilah yang mendasari keputusan membeli bahkan loyalitas merek (brand loyalty) dari konsumen. Citra merek meliputi pengetahuan dan kepercayaan akan atribut merek (aspek kognitif), konsekuensi dari penggunaan merek tersebut dan situasi penggunaan yang sesuai, begitu juga dengan evaluasi, perasaan dan emosi yang dipresepsikan dengan merek tersebut (aspek Afektif).

Menurut Kotler dan Keller (2009:346), citra merek adalah sekumpulan asosiasi merek yang terbentuk dan melekat dibenak konsumen, konsumen yang terbiasa menggunakan merek tertentu cenderung memiliki konsistensi terhadap citra merek. Citra merek ialah persepsi dan keyakinan yang dilakukan oleh konsumen, seperti tercermin dalam asosiasi yang terjadi dalam memori konsumen.

Citra merek (Brand Image) merupakan representasi dari keseluruhan persepsi terhadap merek dan dibentuk dari informasi dan pengalaman masa lalu terhadap merek itu. Menurut Kotler dan Armstrong (2014: 233) menyatakan bahwa citra merek adalah "The set of belief held about a particular brand is known as brand image". Yang artinya kutipan pada halaman sebelumnya adalah sekumpulan keyakinan terhadap suatu merek disebut citra merek.

Citra merek menurut Hermawan Kartajaya bukan hanya logo atau simbol sebuah produk melainkan value yang ditawarkan perusahaan kepada pelanggan. Merk merupakan aset yang menciptakan value bagi pelanggan dengan memperkuat kepuasan dan loyalitasnya. Merek merupakan hasil dari setiap langkah-langkah (strategi) yang dilakukan perusahaan dalam membangun dan mengembangkan produk. Suatu merk dikatakan memiliki value yang tinggi apabila merk tersebut memberikan rasio yang tinggi kepada pelanggan antara total get dan total give.

\section{Keputusan Pembelian}

Keputusan pembelian menurut Kotler (2012:170) merupakan tahap evaluasi, konsumen dari preferensi di antara merek di set pilihan dan mungkin juga dari niat untuk membeli merek yang paling disukai. Daryanto (2011:94), pada dasarnya keputusan pembelian sangat dipengaruhi oleh motif- motif pembelian dimana bisa karena pembeli melaksanakan pembelian hanya pertimbangan (motif=terdorong) secara emosional, seperti bangga, sugesti dan sebagainya, tetapi juga pembeli membeli secara rasional seperti harganya. Alma (2011:96), keputusan pembelian merupakan suatu keputusan konsumen yang dipengaruhi oleh ekonomi keuangan, teknologi, politik, budaya, produk, harga, lokasi, promosi, physical evidence, people dan proces, sehingga membentuk suatu sikap pada konsumen untuk mengolah segala informasi dan mengambil kesimpulan berupa responce yang muncul produk apa yang akan dibeli.

\section{METODE}

\section{Ruang Lingkup Penelitian}

$\underline{\text { Lokasi Penelitian }}$

Dalam penelitian ini peneliti mengambil lokasi penelitian pada PT. Astra International, TbkToyota Auto 2000 Bumi Serpong Damai yang merupakan tempat menyebar kuesioner yang beralamat BSD Komersial VII C No.2 \& 2A Serpong Tangerang. 
Pertimbangan memilih lokasi tersebut karena Auto 2000 Bumi Serpong Damai sebagai salah satu perusahaan yang bergerak dalam bidang otomotif yang menyediakan penjualan, jasa perbaikan kendaraan Toyota dan juga sebagai penyedia suku cadang Toyota (After Sales Service Toyota).

\section{Waktu Penelitian}

Penelitian ini dilakukan dalam kurun waktu tiga bulan yaitu 1 Oktober 2016 sampai dengan 31 Desember 2016 hingga mencukupi kebutuhan data dan informasi. Penelitian ini dilakukan secara bertahap disertai dengan pra survei mulai dari pendahuluan, pengajuan proposal, pengajuan surat ijin, konsultasi dan pembuatan kuesioner serta pengolahan data penyusunan skripsi.

\section{Sifat Penelitian}

Sifat penelitian ini merupakan penelitian diskriptif kuantitatif yaitu penelitian tentang data yang dikumpulkan dan dinyatakan dalam bentuk angka-angka meskipun juga berupa data kualitatif sebagai pendukungnya, seperti kata- kata atau kalimat yang tersusun dalam angket, kalimat hasil konsultasi atau wawancara antara peneliti dan informan.

\section{Metode Penentuan Sample}

\section{Populasi}

Populasi adalah wilayah generasi yang terdiri dari objek atau subjek yang mempunyai kualitas dan karakteristik tertentu yang ditetapkan oleh peneliti untuk dipelajari dan kemudian ditarik kesimpulannya, Sugiyono (2010:57). Populasi dalam penelitian ini adalah pelanggan Toyota yang melakukan service berkala di cabang Auto 2000 Bumi Serpong Damai. Jadi jumlah responden yang diteliti sebanyak 624 pelanggan.

\section{Sampel}

Sampel adalah bagian dari populasi yang memiliki karakteristik yang sama dengan karakteristiknya, Sugiyono (2010:116). Peneliti menghadapi kasus dimana jumlah populasi yang ada sangat banyak (sulit diketahui secara pasti), sehingga teknik pengambilan sampel yang digunakan adalah teknik Non- Probability Sampling, yaitu teknik pengambilan sampel dengan tidak memberikan kesempatan yang sama bagi setiap unsur atau anggota populasi untuk dipilih menjadi sampel dan dengan metode Purposive Sampling, yaitu pengambilan sampel yang dipilih secara cermat dengan mengambil objek penelitian yang selektif dan mempunyai ciri-ciri yang spesifik.

Sampel dalam penelitian ini mempunyai kriteria tertentu, adapun kriteria tersebut sebagai berikut:

a) Pelanggan yang service berkala di Auto 2000 Bumi Serpong Damai

b) Merupakan pengguna mobil Toyota Yaris

Dalam penelitian ini penulis menggunakan Rumus Slovin dengan cara sebagai berikut:

$$
n=\frac{N}{1+N(e)^{2}}
$$

Keterangan:

n: Jumlah sample

$\mathrm{N}$ : Jumlah populasi

e: Batas toleransi kesalahan (error tolerance)

Jumlah responden yang diteliti sebanyak 624 pelanggan dengan batas toleransi kesalahan 10\%. Dengan menggunakan rumus Slovin:

$$
\begin{gathered}
n=\frac{N}{1+N(e)^{2}} \\
n=\frac{624}{1+624 \times 0.1^{2}} \\
n= \\
86,18
\end{gathered}
$$

Dibulatkan menjadi, $\mathrm{n}=86$ Dengan demikian, jumlah sample yang dibutuhkan adalah 86 pelanggan.

\section{HASIL DAN PEMBAHASAN}

\section{Uji Hipotesis / Uji t}

Menetukan rumusan hipotesisnya adalah:

$\mathrm{H}_{\mathrm{O}}: \rho=0$ Tidak terdapat pengaruh positif dan signifikan antara citra merekterhadap keputusan pembelian pada PT. Astra International Tbk.

H1: $\rho \neq 0$ Terdapat pengaruh positif dan signifikan antara citra merek terhadap keputusan pembelian pada PT. Astra 
International Tbk.

Sedangkan untuk mengetahui hipotesis ditolak atau diterima, maka diberlakukan ketentuan untuk uji t yaitu:

a. Jika t hitung $<\mathrm{t}$ tabel, maka Ho diterima dan $\mathrm{H} 1$ ditolak.

b. Jika t hitung $>\mathrm{t}$ tabel, maka Ho ditolak dan $\mathrm{H} 1$ diterima.

Untuk menentukan nilai t hitung, maka dihitung dengan rumus:

$$
\frac{\mathrm{r} \sqrt{\mathrm{n}-2}}{\sqrt{-r^{2}}}
$$

Untuk selanjutnya dalam menentukan besarnya nilai $t_{\text {tabel }}$ maka dicari dengan menggunakan rumus berikut,

$$
t_{\_} \text {tabel }=t
$$

$\propto . d f$ (Taraf Alpha $x$ Degree of Freedom)

$\alpha=$ taraf nyata $5 \%$, df $=(n-2)$, maka diperoleh $(86-2)=84$, t tabel $=1,9886$

\begin{tabular}{|c|c|c|c|c|c|c|}
\hline \multicolumn{7}{|c|}{ Hipotesis/Uji tCoefficients ${ }^{a}$} \\
\hline \multirow{3}{*}{\multicolumn{2}{|c|}{ Model }} & $\begin{array}{r}\text { Un } \\
r \\
\text { Coe }\end{array}$ & $\begin{array}{l}\text { tanda } \\
\text { ized } \\
\text { ficients }\end{array}$ & $\begin{array}{c}\text { Standar } \\
\text { dized } \\
\text { Coeffcie } \\
n t s\end{array}$ & \multirow{3}{*}{$\mathrm{T}$} & \multirow{3}{*}{ Si g } \\
\hline & & \multirow[b]{2}{*}{ B } & \multirow[t]{2}{*}{$\begin{array}{l}\text { Std. } \\
\text { Error }\end{array}$} & \multirow[b]{2}{*}{ Beta } & & \\
\hline & & & & & & \\
\hline \multirow[t]{4}{*}{1} & (Constant) & 16.5 & 3.4 & & 4.8 & .0 \\
\hline & & 46 & 38 & & 13 & 00 \\
\hline & Citra & & .08 & \multirow{2}{*}{.602} & 6.9 & .0 \\
\hline & Merek & $\begin{array}{c}.58 \\
3\end{array}$ & 4 & & 07 & 00 \\
\hline
\end{tabular}

Tabel 2. Hasil Pengolahan Data Pengujian

a. Dependent Variable: Keputusan Pembelian

Sumber: Data primer hasil pengolahan SPSS versi $22(2018)$

Berdasarkan perhitungan pada tabel 4.15 di atas diperoleh nilai t hitung $>\mathrm{t}$ tabel atau $(6,907>$ 1,9886), hal ini juga diperkuat dengan nilai signifikansi $0,000<0,05$, maka dapat dikatakan signifikan. Artinya $\mathrm{H}_{0}$ ditolak dan $\mathrm{H} 1$ diterima, berarti terdapat pengaruh yang positif dan signifikan antara citra merek terhadap keputusan pembelian.

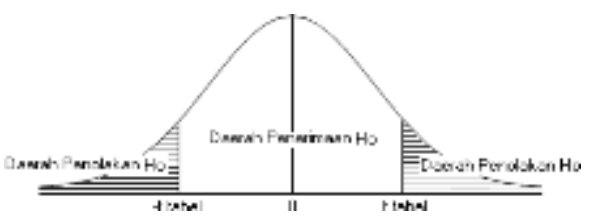

Gambar 1. Kriteria Penentuan Penerimaan Hipotesis

\section{KESIMPULAN}

Berdasarkan hasil analisis dan pembahasan maka dapat disajikan beberapa kesimpulan yaitu sebagai berikut:

Citra Merek masih di persepsikan baik (B). Hal itu dapat di lihat dari rata-rata nilai score 3,50 ada pada interval 3,40-4,19 dengan interprestasi Baik. Citra Merek berpengaruh terhadap keputusan pembelian mobil Toyota Yaris pada PT.Astra International Tbk-Toyota Auto 2000 Bumi Serpong Damai. Dimana dapat dilihat bahwa dengan adanya peningkatan Citra Merek akan selalu diikuti oleh keputusan pembelian.

Keputusan Pembelian masih di persepsikan baik (B). Hal itu dapat di lihat dari rata- rata nilai score 3,47 ada pada interval 3,40-4,19 dengan interprestasi Baik. Terdapat pengaruh antara citra merek dengan keputusan pembelian mobil Toyota Yaris pada PT. Astra International TbkToyota Auto 2000 Bumi Serpong Damai.

Terdapat pengaruh positif yang Kuat dan signifikan antara Citra Merek terhadap Keputusan Pembelian dengan nilai regresi sebesar 0,583. Nilai koefisien korelasi (r) sebesar 0,602 dan nilai determinasi (Kd) sebesar 0,362 atau $36,2 \%$ sedangkan sisanya sebesar $63,8 \%$ dipengaruhi oleh faktor lain. Pengujian hipotesis menggunakan uji statistik t hitung diperoleh $\mathrm{t}$ hitung $>\mathrm{t}_{\text {tabel }}(6,907>1,9886)$, hal ini juga diperkuat dengan nilai signifikansi $0,000<0,05$, maka dapat dikatakan signifikan. Dengan demikian $\mathrm{H} 0$ ditolak dan $\mathrm{H} 1$ diterima artinya terdapat pengaruh yang positif dan signifikan antara Citra Merek terhadap Keputusan Pembelian.

Berdasarkan hasil penelitian dan kesimpulan diatas, maka saran yang dapat penulis sampaikan sebagai berikut.

Pihak perusahaan sebagai penyedia produk harus memiliki pilihan type sesuai dengan 
kebutuhan masyarakat dan harus terus meningkatkan kualitas produk yang dihasilkan demi terpenuhinya harapan konsumen, dan konsumen merasa bahwa type produk yang dikeluarkan hasilnya sesuai dengan apa yang diharapkan. Sehingga tercipta loyalitas konsumen yang dapat memberikan dampak terhadap pembelian. Toyota perlu memfokuskan kebijakan pemasarannya pada harga purna jual yang stabil sehingga dapat berusaha untuk mempertahankan atau memelihara serta meningkatkan kekuatan asosiasi merek mobil Toyota

\section{UCAPAN TERIMA KASIH}

Penulis Bersyukur Kehadirat Dan Berkat Tuhan Yang Maha Esa, khususnya kepada Universitas Al-Azhar Indonesia, kepada orang tua yang selalu mendoakan penulis, kepada suami tercinta dan anak-anak yang saya sayangi dan cintai. dukungan dari rekan dosen manajemen di Universitas Pamulang.

\section{DAFTAR PUSTAKA}

Alma, Buchari, 2007. Manajemen dan Pemasaran Jasa, Penerbit PT. Alfabeta, Cetakan Kesembilan, Bandung.

Ardana. 2012. Manajemen Sumber Daya Manusia. Yogyakarta: Graha Ilmu.

Daryanto. 2011. Sari Kuliah Manajemen Pemasaran, Bandung: PT. Sarana
Ferinda dewi, Erna. 2008. Merek dan Psikolog

i Konsumen, Implikasi pada Strategi Pemasaran. Yogyakarta: Graha Ilmu.

Hasan, Misbahudin Iqbal. 2013. Analisis Data Penelitian Dengan Statistik. Jakarta: PT. $\mathrm{Bu}, \mathrm{I}$ Aksara.

Kotler. 2009. Manajemen Pemasaran. Jilid 1, Edisi ketigabelas, Erlangga, Jakarta. . 2012. Manajemen Pemasaran, Analisis Perencanaan dan Pengendalian, (Terjemahan Ancella Anitawati Hermawan), Jilid II, Edisi 9, Prehallindo, Jakarta.

dan Garry Amstrong. 2014. Citra Merek dan Prinsip-Prinsip Pemasaran Edisi 12. Jilid 1. Jakarta: Erlangga.

Sugiyono. 2013. Metode Penelitian Kuantitatif Kualitatif dan R\&D. Bandung : Alfabeta

Tjiptono, Fandy. 2009. Strategi Pemasaran. Yogyakarta, Penerbit Andi. .2015. Strategi Pemasaran, Edisi 4, Penerbit Andi, Yogyakarta. 